\title{
REGIONAL DISPARITIES OF SCHEDULED COMMERCIAL BANKING DEVELOPMNET IN RURAL AREAS
}

\author{
Prof. K.C Sharma ${ }^{1}$, Monika Parmar ${ }^{2}$ \\ ${ }^{1}$ Chairman, Department of Economics, Himachal Pradesh University, Shimla-171005. \\ ${ }^{2}$ Research Scholar, Department of Economics, Himachal Pradesh University, Shimla-171005. \\ DOI: 10.46609/IJSSER.2020.v05i09.014 URL: https://doi.org/10.46609/IJSSER.2020.v05i09.014
}

\begin{abstract}
The present study endeavors to analyze the extent and disparities of scheduled commercial banks from 1981-2018 in rural areas. The study has been conducted in selected states and the growth of these states has been evaluated with the help of deposit penetration, credit mobilization and branch expansion based indicators. Various statistical tools i.e. compound growth rate, coefficient of variation, combined mean, deprivation index and development index have been used. The finding of the study shows that there exist inter-state disparities in various indicators of rural banking development. With the introduction of economic reform, the situation of backward states in rural areas has improved but these states still not perform at the par with the developed state.
\end{abstract}

Keywords: Banking, Rural Area, Finance , Mobilization, disparities .

\section{Introduction}

Economic Development is the main concern of all the societies and nations. But, as economic development proceeds, some regions of the economy grow much faster than others, while many others remain neglected. Regional Disparities are almost inevitable in the course of development as some regions offer more advantages than others and regions which gain a lead tend to become more and more prosperous. ${ }^{i}$ Disparities in economic development are one of the common features found in all over the world today which denotes as regional imbalances or regional dualism or growth differentiation. The prevalence of regional disparities is the common phenomenon in the economy because even the richest country of the world like USA even has this problem of regional imbalanced and many small country (Italy and France) and Socialist countries are also facing this same situation of different regions of the country grow at unequal rates, resulting interregional and intra regional disparities which resulted socio- economic 


\section{International Journal of Social Science and Economic Research}

ISSN: 2455-8834

Volume:05, Issue:09 "September 2020"

problem. $^{\text {ii }}$

Role of financial infrastructure for economic development in the context of developing economy is greater as compared to that in developed economy. In underdeveloped economy, financial infrastructure in the form of banking and non-banking financial institutions and development banks provides necessary capital, enterprises, managerial and technical knowhow where these are clearly inadequate or no available and also assists in building up the economic development. ${ }^{\text {iii }}$

The present Indian financial system is large with the variety of banks, financial institutions, capital market institutions, non banking institutions and a number of indigenous banks. Among the financial institutions in India, banks are the predominant financial intermediaries and in fact financial inter mediation is largely synonymous with banking. ${ }^{\text {iv }}$ The commercial banks play a vital role in the process of economic development and achievement of social justice. This can be facilitated through extension and expansion of banking facilities in unbanked and under-banked areas, mobilization of savings to meet investment requirement of an economy and allocation of credit for developmental purposes with focus on priority sector lending so as to provide relief to the farmers from the clutches of money lenders and to improve growth of employment, diversification of banking activities based on the changing needs of the customers and improvement in productivity, profitability and quality of customer care. Further, one of the major changes in the banking sector was the concept of 'social banking' which makes a shift from urban centric growth to rural -oriented growth strategy. Some of the studies have been conducted on various aspect of commercial banks in India. Few studies have been reviewed in the context of regional disparities in the present study. Bhawna (2017) $\mathbf{v}$ explained the inter-state variations in level of financial inclusion in India by providing potential correlations in terms of demographic and economic factors. She concluded that period of fourteen years showed continuous improvement in context of credit and deposit penetration. These two indicators were positively correlated implying that the regions having high credit penetration also having high deposit penetration and vice versa but disparities still exist in the country. Saluja (2014) vi highlighted the social economic development made by commercial banks in reducing the regional disparities in India by population group wise i.e. rural, semi urban and urban metropolitan. She revealed that in the rural areas distribution of the outstanding credit was more in case of agriculture as compared to industry. Likewise, in Semi urban areas the situation is similar to rural areas, the standard deviation was high in agriculture which showed more variability and low in case of transport operation indicate more homogeneity. However, in case of urban areas outstanding was more in case of Industry as compared to agriculture sector. Ravi Kumar (2012) ${ }^{\mathbf{v i i}}$ made an attempt to assessed the role of banking sector in financial inclusion with the help of various indicators i.e. branch and ATM penetration population per branch, 


\section{International Journal of Social Science and Economic Research}

ISSN: $2455-8834$

Volume:05, Issue:09 "September 2020"

distribution of banking branches and credit and cash deposit ratio in India. From the finding, he ascertained that number of scheduled commercial bank branches had been declined in the rural areas between 1991 and 2001 but in semi urban and urban areas it was increasing significantly. Since the year 2008, number of branches in all kind of areas has been increased but percentage of the increment was low in rural areas as compared to other areas. He also evaluated that there prevail disparities in population and region wise as the credit accounts were increasing particularly in urban areas. The north eastern, eastern and central regions recorded low saving accounts and credit accounts whereas the northern, southern and western region showed greater concentration of these two accounts. Further, in case of ATM penetration, there has been considerable increase in this field but not in proportion to increase in population. Kumar and Mishra (2011) ${ }^{\text {viii }}$ studied the measurement and understand financial inclusion by using supply of banking outreach indicator such as number of deposit and credit accounts, number of bank branches, deposit and credit per account and demand indicator of household level access such as saving, credit and insurance facilities from formal as well as informal sources of financial service for the time period of 2002-03. They noticed disparities across states, for rural and urban areas it was found that Pondicherry state did well in rural area but not in urban area while Kerala state performed better in urban area and poorly in rural areas. Further, it was also evaluated from the study that some states which have good availability of banks and high number of deposits and credit accounts, but these services were confined to a smaller set of people while rest of the population has to rely on informal sources. Further, States like Bihar, Uttar Pradesh, Manipur, Rajasthan and Madhya Pradesh were those states which performed poorly in both indicators. Kumar and Golait (2009) $)^{\text {ix }}$ studied that the aftermath of nationalization has a remarkable spread of banking system to the unbanked and under banked rural areas but over the year, the spread of commercial banking network in India has skewed in favour of metropolitan areas which mean the share of semi urban and urban centers has declined in credit outstanding during the period under study. Further, the credit deposit ratio has increased during 1991 to 2006 in population group wise but more in metropolitan area. It was also observed that southern, northern and western regions have recorded higher banking density as compared to north east, central and eastern region.

\section{Objectives:}

1. to analyze the extent and disparities of scheduled commercial banks in rural areas; and

2. to identify the backward states with respect to banking in rural areas in India.

\section{Methodology}

The present study seeks to measure the extent of regional disparities in banking services in rural areas. 
The scope of study has been confined to the selected 21 states and the reference period is going to be from the year 1981 to 2018 . The time series data will be collected for the analysis purposes. The study period is going to be divided into three phases. The first phase will be pre-reform period covering the time 1981-1990. Further, the post reform period has been divided into two phases i.e. early reform period (second phase) which included the period from 1991-2004 and later reform period (Third phase) covered period from 2005-2018.

\section{STATISTICAL TOOLS OF THE STUDY}

In order to evaluate a realistic magnitude of the growth and extent of interstate disparities various indicators are framed with respect to population group wise (Rural and Urban) and priority sector lending (Agriculture and small scale industries) are framed. In general to make analysis simple and more understandable various tools have been used. For example Compound growth rate, combined mean, coefficient of variation, deprivation index and development index are used.

\section{- Compound Growth Rate (CAGR)}

Compound growth rate of various items were estimated by the least square technique of fitting the exponential function of the form

$\mathrm{Yi}=\mathrm{abi}^{\mathrm{t}}$

And C.G.R $=(b-1) * 100$

$\mathrm{b}=$ Antilog of $\log$

$$
\mathrm{N} \sum(\mathrm{t} \log \mathrm{Y})-\sum \mathrm{t} \sum \log \mathrm{Y}
$$

\section{Where $\log b$}

$$
\mathrm{N} \sum \mathrm{x}^{2}-\left(\sum \mathrm{t}^{2}\right)
$$

$Y i$ is the value of $i^{\text {th }}$ indicator $t=$ time variable

$\mathrm{a}=$ constant

$\mathrm{n}=$ number of observation

- COMBINED MEAN 


\section{The Combined Mean =}

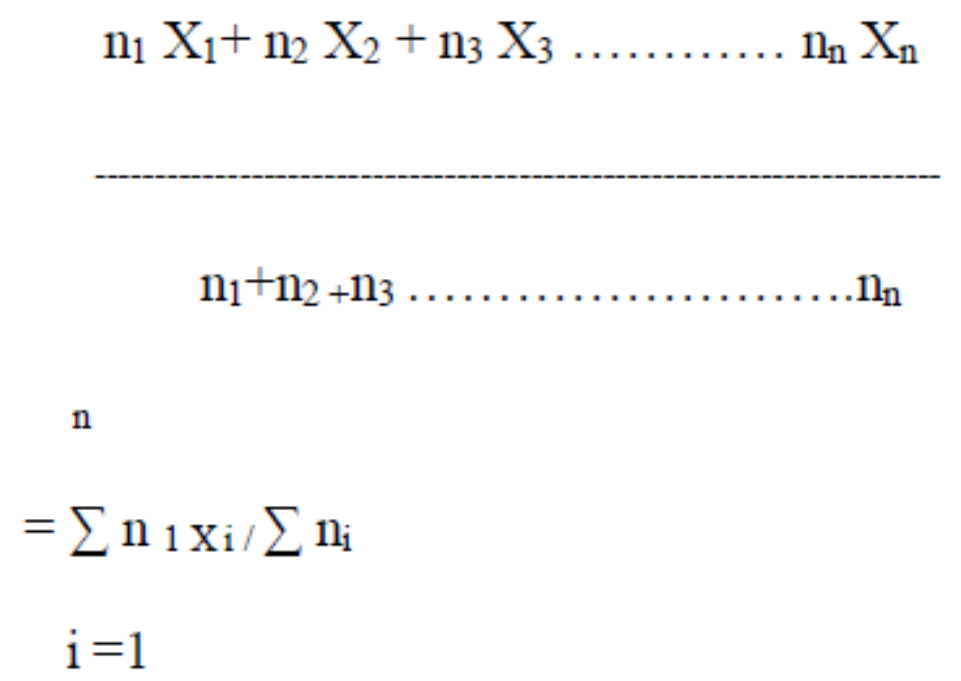

Where, ni stands for number of observations and Xi stands for mean value.

\section{- COEFFICIENT OF VARIATION}

The behavior of inequalities in banking development will seek to be explained with the help of co-efficient of variation also. The trends in co- efficient of variation will also be ascertained to study the direction in regional disparities in each indicator in each state over the period of time. The co-efficient of variation will be ascertained as follows:

$$
C . V=\frac{\sigma_{i}}{\bar{X}_{i}}
$$

Where C.V. stands for co-efficient of variation,

$\sigma_{I}$ is the standard deviation of $i^{\text {th }}$ indicator

$\bar{X} i$ is the mean value of $i^{\text {th }}$ indicator.

\subsubsection{DEPRIVATION INDEX}

The approach allows the separate measurement of different dimensions of deprivation. 
International Journal of Social Science and Economic Research

ISSN: 2455-8834

Volume:05, Issue:09 "September 2020"

Maximum Value - Actual Value

Deprivation Index =

Maximum Value - Minimum Value

\section{DEVELOPMENT INDEX:}

Development Index $=1$ - Deprivation Index

\section{INTER-STATE DEVELOPMENT INDEX IN BANKING SECTOR DEVELOPMENT IN RURAL AREAS}

\section{Deposit per Rural Branch}

\begin{tabular}{|c|c|c|c|c|c|c|}
\hline States & $\begin{array}{c}\text { First } \\
\text { Phase(1981-1990) }\end{array}$ & Rank & $\begin{array}{c}\text { Second } \\
\text { Phase(1991-2004) }\end{array}$ & Rank & $\begin{array}{c}\text { Third } \\
\text { Phase(2005-2018) }\end{array}$ & Rank \\
\hline HR & 0.55 & 4 & 0.62 & 4.5 & 0.2 & 10 \\
\hline H P & 0.47 & 6 & 0.6 & 6 & 0.42 & 4 \\
\hline J\&K & 0.2 & 16 & 0.42 & 8 & 0.36 & 5 \\
\hline PB & 1 & 1 & 1 & 1 & 0.49 & 3 \\
\hline RJ & 0.17 & 17 & 0.23 & 15 & 0 & 21 \\
\hline ASS. & 0.31 & 10 & 0.25 & 13 & 0.25 & 8 \\
\hline MANI. & 0 & 21 & 0 & 21 & 0.02 & 18.5 \\
\hline MEGH. & 0.25 & 14 & 0.17 & 20 & 0.18 & 11.5 \\
\hline NAGA. & 0.68 & 2 & 0.88 & 2 & 1 & 1 \\
\hline TRIP. & 0.15 & 18.5 & 0.21 & 17 & 0.18 & 11.5 \\
\hline BIH. & 0.26 & 13 & 0.29 & 11 & 0.15 & 14.5 \\
\hline ORRS. & 0.09 & 20 & 0.19 & 18.5 & 0.17 & 13 \\
\hline WB & 0.44 & 7 & 0.34 & 10 & 0.32 & 7 \\
\hline MP & 0.15 & 18.5 & 0.19 & 18.5 & 0.03 & 17 \\
\hline UP & 0.33 & 8 & 0.36 & 9 & 0.1 & 16 \\
\hline GJ & 0.56 & 3 & 0.53 & 7 & 0.35 & 6 \\
\hline MH & 0.27 & 12 & 0.22 & 16 & 0.15 & 14.5 \\
\hline AP & 0.29 & 11 & 0.27 & 12 & 0.02 & 18.5 \\
\hline KN & 0.22 & 15 & 0.24 & 14 & 0.01 & 20 \\
\hline KERL. & 0.51 & 5 & 0.8 & 3 & 0.63 & 2 \\
\hline TN & 0.32 & 9 & 0.62 & 4.5 & 0.21 & 9 \\
\hline & & & & & & \\
\hline
\end{tabular}




\section{International Journal of Social Science and Economic Research}

ISSN: 2455-8834

Volume:05, Issue:09 "September 2020"

Source: Compiled on The Basis of Various Statistical Tables Relating To Banks in India, Banking

Statistics: Basic Statistical Returns of Scheduled Commercial Banks and Report on Trends and Progress of Banking in India

The table reveals that the development index score with respect to the deposit per rural branch was observed highest in Punjab followed by Nagaland, Gujarat, Haryana and Kerala respectively whereas, Manipur was placed at the bottom preceded immediately by Orissa, Tripura, Madhya Pradesh and Rajasthan respectively during the first phase. Similarly, in second phase, it was Punjab which holds its first position in deposit per rural branch development index score followed by Nagaland, Kerala, Tamil Nadu and Haryana respectively, whereas, Manipur was placed at the bottom preceded by Meghalaya, Orissa, Madhya Pradesh and Tripura. Lastly, in the third phase, the highest development index score was registered in Nagaland followed by Kerala, Punjab and Himachal Pradesh with respect to deposit per branch while, Rajasthan found at the bottom list preceded by Karnataka, Andhra Pradesh, Manipur and Madhya Pradesh respectively.

\section{Credit per Rural Branch}

\begin{tabular}{|c|c|c|c|c|c|c|}
\hline States & $\begin{array}{c}\text { First } \\
\text { Phase(1981- } \\
\mathbf{1 9 9 0 )}\end{array}$ & Rank & $\begin{array}{c}\text { Second } \\
\text { Phase(1991- } \\
\mathbf{2 0 0 4 )}\end{array}$ & Rank & $\begin{array}{c}\text { Third } \\
\text { Phase(2005- } \\
\mathbf{2 0 1 8})\end{array}$ & Rank \\
\hline HR & 0.89 & 2 & 0.75 & 3.5 & 0.66 & 5 \\
\hline H P & 0.34 & 11 & 0.33 & 10 & 0.25 & 12 \\
\hline J\&K & 0.02 & 20 & 0.13 & 19 & 0.29 & 11 \\
\hline PB & 1 & 1 & 1 & 1 & 0.75 & 3.5 \\
\hline RJ & 0.22 & 15.5 & 0.28 & 12 & 0.38 & 9 \\
\hline ASS. & 0.32 & 12 & 0.19 & 16.5 & 0.22 & 13.5 \\
\hline MANI. & 0.11 & 18 & 0.19 & 16.5 & 0.14 & 16.5 \\
\hline MEGH. & 0 & 21 & 0 & 21 & 0.02 & 20 \\
\hline NAGA. & 0.41 & 8 & 0.35 & 9 & 0.42 & 8 \\
\hline TRIP. & 0.4 & 9 & 0.24 & 14 & 0.14 & 16.5 \\
\hline BIH. & 0.1 & 19 & 0.12 & 20 & 0 & 21 \\
\hline ORRS. & 0.27 & 13 & 0.29 & 11 & 0.13 & 18 \\
\hline WB & 0.22 & 15.5 & 0.17 & 18 & 0.08 & 19 \\
\hline MP & 0.17 & 17 & 0.23 & 15 & 0.22 & 13.5 \\
\hline UP & 0.24 & 14 & 0.27 & 13 & 0.15 & 15 \\
\hline GJ & 0.54 & 6 & 0.5 & 7 & 0.34 & 10 \\
\hline MH & 0.36 & 10 & 0.42 & 8 & 0.47 & 7 \\
\hline AP & 0.57 & 5 & 0.64 & 5 & 0.75 & 3.5 \\
\hline KN & 0.46 & 7 & 0.55 & 6 & 0.49 & 6 \\
\hline KERL. & 0.62 & 4 & 0.78 & 2 & 0.79 & 2 \\
\hline TN & 0.66 & 3 & 0.75 & 3.5 & 1 & 1 \\
\hline
\end{tabular}

Source: Compiled on The Basis of Various Statistical Tables Relating To Banks in India, Banking Statistics: Basic Statistical Returns of Scheduled Commercial Banks and Report on Trends and Progress of Banking in India 


\section{International Journal of Social Science and Economic Research}

ISSN: 2455-8834

Volume:05, Issue:09 "September 2020"

The table shows that in the first phase the highest development index score in credit per branch in respect of credits per rural branch was observed in Punjab followed by Haryana,Tamil Nadu, Kerala and Andhra Pradesh respectively whereas, Meghalaya placed at the bottom preceded by Bihar, Jammu and Kashmir, Manipur and Madhya Pradesh respectively. In the second period, it was Punjab which occupied first place in the development index score in respect of credit per rural branch followed by Kerala, Tamil Nadu, Haryana and Andhra Pradesh respectively, while, Meghalaya placed at the bottom preceded by Bihar, Jammu and Kashmir, West Bengal, Assam and Manipur respectively. Similarly, during the third Phase, Tamil Nadu placed at top with respect to the highest rural credit per rural branch followed by Kerala, Punjab and Andhra Pradesh respectively whereas, Bihar followed by Meghalaya, West Bengal, Orissa, Tripura and Manipur respectively.

\section{Credit-Deposit Ratio}

\begin{tabular}{|c|c|c|c|c|c|c|}
\hline States & $\begin{array}{c}\text { First } \\
\text { Phase(1981- } \\
\mathbf{1 9 9 0 )}\end{array}$ & Rank & $\begin{array}{c}\text { Second } \\
\text { Phase(1991- } \\
\text { 2004) }\end{array}$ & Rank & $\begin{array}{c}\text { Third } \\
\text { Phase(2005- } \\
\text { 2018) }\end{array}$ & Rank \\
\hline HR & 0.53 & 7 & 0.36 & 8.5 & 0.62 & 4 \\
\hline H P & 0.13 & 16 & 0.08 & 17.5 & 0.12 & 17 \\
\hline J\&K & 0.12 & 17 & 0.08 & 17.5 & 0.15 & 15 \\
\hline PB & 0.18 & 15 & 0 & 21 & 0.42 & 7 \\
\hline RJ & 0.46 & 8 & 0.35 & 10 & 0.57 & 5 \\
\hline ASS. & 0.26 & 12 & 0.24 & 13 & 0.17 & 14 \\
\hline MANI. & 1 & 1 & 1 & 1 & 0.37 & 8 \\
\hline MEGH. & 0 & 20.5 & 0.03 & 20 & 0.04 & 18 \\
\hline NAGA. & 0.02 & 19 & 0.07 & 19 & 0 & 21 \\
\hline TRIP. & 0.79 & 3 & 0.54 & 5 & 0.14 & 16 \\
\hline BIH. & 0.1 & 18 & 0.12 & 15 & 0.02 & 19.5 \\
\hline ORRS. & 0.87 & 2 & 0.48 & 7 & 0.19 & 13 \\
\hline WB & 0 & 20.5 & 0.11 & 16 & 0.02 & 19 \\
\hline MP & 0.41 & 9.5 & 0.36 & 8.5 & 0.35 & 9.5 \\
\hline UP & 0.2 & 13 & 0.19 & 14 & 0.21 & 11 \\
\hline GJ & 0.19 & 14 & 0.29 & 11 & 0.2 & 12 \\
\hline MH & 0.41 & 9.5 & 0.51 & 6 & 0.52 & 6 \\
\hline AP & 0.64 & 6 & 0.72 & 2 & 1 & 1 \\
\hline KN & 0.68 & 4 & 0.67 & 3.5 & 0.71 & 3 \\
\hline KERL. & 0.31 & 11 & 0.25 & 12 & 0.35 & 9.5 \\
\hline TN & 0.65 & 5 & 0.67 & 3.5 & 0.91 & 2 \\
\hline
\end{tabular}

Source: Compiled on The Basis of Various Statistical Tables Relating To Banks in India, Banking Statistics: Basic Statistical Returns of Scheduled Commercial Banks and Report on Trends and Progress of Banking in India

It may be observed that during the first phase, the development index score in respect of the credit-deposit ratio was highest in Manipur as the reason of higher ratio was due to substantial inflow of credit followed by Orissa, Tripura, Karnataka, Tamil Nadu and Andhra Pradesh respectively, whereas, Meghalaya placed at bottom preceded by West Bengal, Nagaland, Bihar and Jammu and Kashmir respectively. During second phase, it was Manipur which recorded 


\section{International Journal of Social Science and Economic Research}

ISSN: 2455-8834

Volume:05, Issue:09 "September 2020"

maximum development index score followed by Andhra Pradesh, Karnataka, Tamil Nadu and Tripura respectively, while Punjab placed at the bottom preceded by Meghalaya, Nagaland and Himachal, Jammu and Kashmir and West Bengal. Similarly, during the third phase, it was Andhra Pradesh which registered maximum development index score with respect to creditdeposit ratio followed by Tamil Nadu, Karnataka, Haryana and Rajasthan respectively, whereas Nagaland placed at the bottom list preceded by Bihar, West Bengal, Meghalaya and Himachal Pradesh respectively.

\section{Populations per Rural Branch}

\begin{tabular}{|c|c|r|r|r|r|c|}
\hline States & $\begin{array}{c}\text { First } \\
\text { Phase(1981- } \\
\mathbf{1 9 9 0}\end{array}$ & Rank & $\begin{array}{c}\text { Second } \\
\text { Phase(1991- } \\
\text { 2004) }\end{array}$ & Rank & $\begin{array}{c}\text { Third } \\
\text { Phase(2005- } \\
\text { 2018) }\end{array}$ & Rank \\
\hline HR & 0.20 & 15 & 0.37 & 13 & 0.28 & 15 \\
\hline H P & 0.00 & 21 & 0.00 & 21 & 0.05 & 20 \\
\hline J\&K & 0.08 & 18 & 0.22 & 17 & 0.27 & 16 \\
\hline PB & 0.02 & 20 & 0.11 & 19 & 0.08 & 19 \\
\hline RJ & 0.32 & 10 & 0.47 & 11 & 0.52 & 6.5 \\
\hline ASS. & 0.72 & 3 & 0.73 & 4.5 & 0.79 & 2 \\
\hline MANI. & 1.00 & 1 & 1.00 & 1 & 1.00 & 1 \\
\hline MEGH. & 0.25 & 12 & 0.27 & 15.5 & 0.42 & 11 \\
\hline NAGA. & 0.24 & 13.5 & 0.78 & 2 & 0.47 & 9 \\
\hline TRIP. & 0.44 & 7 & 0.53 & 7 & 0.41 & 12 \\
\hline BIH. & 0.57 & 4 & 0.71 & 6 & 0.74 & 4.5 \\
\hline ORRS. & 0.45 & 6 & 0.48 & 9.5 & 0.43 & 10 \\
\hline WB & 0.73 & 2 & 0.75 & 3 & 0.77 & 3 \\
\hline MP & 0.37 & 8.5 & 0.49 & 8 & 0.52 & 6.5 \\
\hline UP & 0.52 & 5 & 0.73 & 4.5 & 0.74 & 4.5 \\
\hline GJ & 0.18 & 16 & 0.32 & 14 & 0.32 & 14 \\
\hline MH & 0.37 & 8.5 & 0.48 & 9.5 & 0.48 & 8 \\
\hline AP & 0.31 & 11 & 0.42 & 12 & 0.35 & 13 \\
\hline KN & 0.12 & 17 & 0.20 & 18 & 0.22 & 17 \\
\hline KERL. & 0.05 & 19 & 0.10 & 20 & 0.00 & 21 \\
\hline TN & 0.24 & 13.5 & 0.27 & 15.5 & 0.19 & 18 \\
\hline
\end{tabular}

Source: Compiled on The Basis of Various Statistical Tables Relating To Banks in India, Banking Statistics: Basic Statistical Returns of Scheduled Commercial Banks and Report on Trends and Progress of Banking in India

the table that during the first phase, the development index score with respect to the population served per rural branch was observed in Manipur followed by Assam, West Bengal Bihar and Uttar Pradesh respectively whereas, Himachal Pradesh was placed at the bottom preceded by Punjab, Kerala, Jammu and Kashmir and Karnataka respectively. Similarly, in second phase, it was Manipur which holds its first position in population served per rural branch development index followed by Nagaland, West Bengal, Assam and Uttar Pradesh respectively, whereas, Himachal Pradesh was placed at the bottom preceded by Punjab, Kerala and Jammu and Kashmir, Meghalaya and Tamil Nadu respectively. Lastly, in the third phase, the highest 
International Journal of Social Science and Economic Research

ISSN: 2455-8834

Volume:05, Issue:09 "September 2020"

development index score with respect to population served per rural branch was registered in Manipur followed by Assam, Bihar, West Bengal, Orissa and Uttar Pradesh respectively while, Kerala found at the bottom list preceded by Himachal Pradesh, Punjab, Tamil Nadu, Karnataka respectively.

\section{Total Businesses per Branch}

\begin{tabular}{|c|c|c|c|c|c|c|}
\hline States & $\begin{array}{c}\text { First } \\
\text { Phase(1981- } \\
\mathbf{1 9 9 0}\end{array}$ & Rank & $\begin{array}{c}\text { Second } \\
\text { Phase(1991- } \\
\mathbf{2 0 0 4}\end{array}$ & Rank & $\begin{array}{c}\text { Third } \\
\text { Phase(2005- } \\
\text { 2018) }\end{array}$ & Rank \\
\hline HR & 0.73 & 2 & 0.74 & 3 & 0.49 & 5 \\
\hline H P & 0.42 & 6 & 0.38 & 7 & 0.28 & 10.5 \\
\hline J\&K & 0.12 & 19 & 0.3 & 9.5 & 0.43 & 7 \\
\hline PB & 1 & 1 & 1 & 1 & 0.84 & 3 \\
\hline RJ & 0.17 & 16 & 0.2 & 15 & 0.13 & 16 \\
\hline ASS. & 0.29 & 10 & 0.2 & 15 & 0.28 & 10.5 \\
\hline MANI. & 0 & 21 & 0 & 21 & 0 & 21 \\
\hline MEGH. & 0.15 & 17 & 0.08 & 20 & 0.09 & 17.5 \\
\hline NAGA. & 0.59 & 3 & 0.58 & 4 & 0.97 & 2 \\
\hline TRIP. & 0.2 & 14 & 0.18 & 17 & 0.17 & 14 \\
\hline BIH. & 0.19 & 15 & 0.2 & 16 & 0.05 & 20 \\
\hline ORRS. & 0.11 & 20 & 0.17 & 18.5 & 0.15 & 15 \\
\hline WB & 0.37 & 8 & 0.27 & 12 & 0.27 & 12 \\
\hline MP & 0.13 & 18 & 0.17 & 18.5 & 0.07 & 19 \\
\hline UP & 0.28 & 11.5 & 0.3 & 9.5 & 0.09 & 17.5 \\
\hline GJ & 0.54 & 4 & 0.5 & 5 & 0.47 & 6 \\
\hline MH & 0.28 & 11.5 & 0.24 & 13 & 0.33 & 9 \\
\hline AP & 0.35 & 9 & 0.34 & 8 & 0.37 & 8 \\
\hline KN & 0.27 & 13 & 0.29 & 11 & 0.2 & 13 \\
\hline KERL. & 0.52 & 5 & 0.79 & 2 & 1 & 1 \\
\hline TN & 0.40 & 7 & 0.47 & 6 & 0.71 & 4 \\
\hline & & & & & & \\
\hline
\end{tabular}

Source: Compiled on The Basis of Various Statistical Tables Relating To Banks in India, Banking Statistics: Basic Statistical Returns of Scheduled Commercial Banks and Report on Trends and Progress of Banking in India

The table elucidates that the development index score with respect to the total business per rural branch during the first phase was observed in Punjab followed by Haryana, Nagaland, Gujarat and Kerala respectively whereas, Manipur was placed at the bottom preceded by Orissa, Jammu and Kashmir, Madhya Pradesh and Meghalaya respectively. Similarly, in second phase, it was Punjab which holds its first position in the total business per rural branch development index score followed by Kerala, Haryana, Nagaland, Gujarat and Tamil Nadu respectively, whereas, Manipur was placed at the bottom preceded by Meghalaya, Madhya Pradesh, Orissa and Tripura respectively. Lastly, in the third phase, the highest development index score with respect to total business per rural branch was registered in Kerala followed by Meghalaya, Punjab, Tamil Nadu and Haryana respectively while, Manipur found at the bottom list preceded by Bihar, Madhya 
International Journal of Social Science and Economic Research

ISSN: 2455-8834

Volume:05, Issue:09 "September 2020"

Pradesh, Meghalaya and Uttar Pradesh respectively.

\section{Rural Credits per State Domestic Product}

\begin{tabular}{|c|c|c|c|c|c|c|}
\hline States & $\begin{array}{c}\text { First } \\
\text { Phase(1981- } \\
\mathbf{1 9 9 0}\end{array}$ & Rank & $\begin{array}{c}\text { Second } \\
\text { Phase(1991- } \\
\text { 2004) }\end{array}$ & Rank & $\begin{array}{c}\text { Third } \\
\text { Phase(2005- } \\
\text { 2018) }\end{array}$ & Rank \\
\hline HR & 0.54 & 5.5 & 0.34 & 8 & 0.31 & 11 \\
\hline H P & 0.91 & 2 & 0.78 & 2 & 0.81 & 3 \\
\hline J\&K & 0.23 & 16 & 0.21 & 16 & 0.75 & 4 \\
\hline PB & 0.72 & 3 & 0.74 & 3 & 0.97 & 2 \\
\hline RJ & 0.34 & 12 & 0.25 & 13 & 0.37 & 9 \\
\hline ASS. & 0.21 & 17 & 0.17 & 17 & 0.3 & 12 \\
\hline MANI. & 0 & 21 & 0.02 & 18 & 0.04 & 19 \\
\hline MEGH. & 0.17 & 18 & 0.01 & 19 & 0.14 & 17 \\
\hline NAGA. & 0.45 & 8 & 0.23 & 14.5 & 0.29 & 13 \\
\hline TRIP. & 0.42 & 9 & 0.28 & 11 & 0.22 & 16 \\
\hline BIH. & 0.27 & 14.5 & 0.33 & 9 & 0.27 & 15 \\
\hline ORRS. & 0.37 & 10.5 & 0.45 & 7 & 0.39 & 8 \\
\hline WB & 0.07 & 20 & 0 & 20.5 & 0 & 21 \\
\hline MP & 0.27 & 14.5 & 0.23 & 14.5 & 0.28 & 14 \\
\hline UP & 0.29 & 13 & 0.31 & 10 & 0.34 & 10 \\
\hline GJ & 0.37 & 10.5 & 0.27 & 12 & 0.1 & 18 \\
\hline MH & 0.10 & 19 & 0 & 20.5 & 0.01 & 20 \\
\hline AP & 0.54 & 5.5 & 0.47 & 5.5 & 0.52 & 6 \\
\hline KN & 0.57 & 4 & 0.54 & 4 & 0.42 & 7 \\
\hline KERL. & 1 & 1 & 1 & 1 & 1 & 1 \\
\hline TN & 0.50 & 7 & 0.47 & 5.5 & 0.71 & 5 \\
\hline
\end{tabular}

Source: Compiled on The Basis of Various Statistical Tables Relating To Banks in India, Banking Statistics: Basic Statistical Returns of Scheduled Commercial Banks and Report on Trends and Progress of Banking in India

Rural Credits per State Domestic Product during three phases of study has been presented in the Table 7.8. the table divulges that during the first phase, the development index score with respect to the Rural Credits Per State Domestic Product was observed in Kerala, followed by Himachal Pradesh, Punjab and Karnataka, Haryana and Andhra Pradesh respectively whereas, Manipur was placed at the bottom preceded by West Bengal, Maharashtra, Meghalaya and Assam respectively. Similarly, in second phase, it was Kerala which holds its first position in Rural Credits Per State Domestic Product development index followed by Himachal Pradesh, Punjab, 


\section{International Journal of Social Science and Economic Research}

ISSN: 2455-8834

Volume:05, Issue:09 "September 2020"

Karnataka, Tamil Nadu and Andhra Pradesh respectively, whereas, West Bengal and Maharashtra was placed at the bottom preceded by Meghalaya, Manipur, Assam and Jammu and Kashmir respectively. Lastly, in the third phase, the highest development index score with respect to Rural Credits per State Domestic Product was registered in Kerala followed by Punjab, Himachal Pradesh and Jammu and Kashmir and Tamil Nadu respectively while, West Bengal found at the bottom list preceded by Maharashtra, Manipur, Gujarat and Meghalaya and Tripura respectively.

Overall Development of scheduled commercial banks in rural areas

\begin{tabular}{|c|c|c|c|c|c|c|}
\hline States & First Phase & Rank & Second Phase & Rank & Third Phase & Rank \\
\hline HR & 0.56 & 2 & 0.51 & 4 & 0.43 & 6 \\
\hline H P & 0.38 & 9.5 & 0.36 & 10 & 0.32 & 12 \\
\hline J\&K & 0.13 & 20.5 & 0.22 & 20 & 0.36 & 7 \\
\hline PB & 0.65 & 1 & 0.64 & 1 & 0.59 & 3 \\
\hline RJ & 0.28 & 17 & 0.3 & 16 & 0.33 & 10 \\
\hline ASS. & 0.35 & 12.5 & 0.3 & 16 & 0.33 & 10 \\
\hline MANI. & 0.35 & 12.5 & 0.37 & 9 & 0.26 & 14.5 \\
\hline MEGH. & 0.13 & 20.5 & 0.09 & 21 & 0.15 & 21 \\
\hline NAGA. & 0.4 & 6.5 & 0.47 & 6 & 0.5 & 5 \\
\hline TRIP. & 0.4 & 6.5 & 0.33 & 13 & 0.21 & 19 \\
\hline BIH. & 0.24 & 19 & 0.3 & 16 & 0.2 & 20 \\
\hline ORRS. & 0.36 & 11 & 0.34 & 11.5 & 0.24 & 17 \\
\hline WB & 0.29 & 16 & 0.25 & 19 & 0.23 & 18 \\
\hline MP & 0.25 & 18 & 0.28 & 18 & 0.25 & 16 \\
\hline UP & 0.31 & 14 & 0.34 & 11.5 & 0.26 & 14.5 \\
\hline GJ & 0.39 & 8 & 0.4 & 8 & 0.3 & 13 \\
\hline MH & 0.3 & 15 & 0.31 & 14 & 0.33 & 10 \\
\hline $\mathbf{A P}$ & 0.45 & 5 & 0.48 & 5 & 0.52 & 4 \\
\hline $\mathbf{K N}$ & 0.38 & 9.5 & 0.42 & 7 & 0.34 & 8 \\
\hline KERL. & 0.5 & 3 & 0.62 & 2 & 0.63 & 1 \\
\hline TN & 0.46 & 4 & 0.54 & 3 & 0.6 & 2 \\
\hline Average & 0.36 & & 0.37 & & 0.35 & \\
\hline CV & 34.95 & & 35.51 & & 40.03 & \\
\hline Rank Correlation & 1 & & 0.90 & & 1 & \\
\hline
\end{tabular}

Source: Compiled on The Basis of Various Statistical Tables Relating To Banks in India, Banking Statistics: Basic Statistical Returns of Scheduled Commercial Banks and Report on Trends and Progress of Banking in India.

The table shows that by examining all indicators of rural area together, found that, Punjab 


\section{International Journal of Social Science and Economic Research}

ISSN: $2455-8834$

Volume:05, Issue:09 "September 2020"

recorded highest developed state followed by Haryana, Kerala, Tamil Nadu, and Andhra Prdaesh during the first phase. Similarly, in the second phase, it was Punjab which registered which maximum score of development index followed by Kerala Haryana, Tamil Nadu, and Haryana respectively. Likewise, in the third phase, these four states again counted as developed states with respect to all indicators but in different sequence. Thus, Kerala followed by Tamil Nadu, Punjab, Andhra Pradesh and Haryana states were ascertained with fast developed states during the reference period. Haryana during third phase, slipped from third position to fourth position as its position was overtook by Tamil Nadu in various indicators such as in case of per capita credit, deposit and credit deposit Ratio, rural credit per 1000 square $\mathrm{km}$, total business per branch and rural credit per state domestic product. Thus, the table depicts that those states where economic activities are high, exhibits high developed states or vice versa.

\section{Conclusion}

Prior to nationalization, rural banking system was neglected. It may become necessity to include each and every person in the regime of banking system after the nationalization therefore, banks set up more branches in neglected areas and unbanked areas which were primarily ignored by commercial banks even though some areas had better infrastructure that resulted highly skewed. However, after reform period, these areas continuously received special attention. The expansion of banks branches leads to reduction in population served per branch. This may also cause expansion of credit and deposit mobilization, improving the banking habits and growing monetization of the economy, priority to provide advance to agriculture and industry sector and weaker section of the society. On the basis of development index of rural banking development Punjab, Haryana, Kerala, Tamil Nadu and Andhra Pradesh were placed in the group of highly developed states throughout the study period. This was mainly due to high economic activities, developed in agriculture sector, small scale industries, better infrastructure, better transport facilities, market facilities, awareness and high per capita income. Apart from these, some states like Himachal Pradesh, Manipur and Nagaland showed better performance. Himachal Pradesh showed its best in case of high per capita deposit and Credit per branch and rural credit per state domestic product. Whereas, Nagaland performed well in case of high deposit per branch, per capita deposit and total business per branch and Manipur in maximum credit deposit ratio and population served per rural branch. However, West Bengal, Bihar, Jammu and Kashmir, Rajasthan, Assam, Meghalaya, Madhya Pradesh and Uttar Pradesh states were examined with less developed states with respect to the indicators of rural banking. It may be observed that the states having strong agriculture base recorded better development as compared to other states. Further, the Overall development index showed that Haryana, Punjab, Andhra Pradesh, Karnataka, Kerala and Tamil Nadu were exhibited with high development index. On the other hand, north east states such as Manipur, Meghalaya, Tripura, Nagaland and Bihar were reported 


\section{International Journal of Social Science and Economic Research}

ISSN: $2455-8834$

Volume:05, Issue:09 "September 2020"

as less developed states with respect to overall analysis of development index.

\section{Suggestion}

- There are inequalities in the distribution of credit between regions/states of the country which make some state developed and some may become under-developed. It may also be observed that the regions/states which do not need or demand for credit have excess supply of credit and vice-versa. Thus, this requires the distribution of credit according to the need of the states and for this Government of India should conduct a survey and frame appropriate measure regarding this indicator.

- Further, it is difficult to make recovery of loan as the person's who lend loans from the banks, use it for other purpose, like paying old debt, for social ceremonies or for another project etc. Thus, in order to stop this type of activities, there should be strict monitoring by banks officials on the usage of these loans.

- Digitalization of land records need to be completed on mission mode in eastern and north eastern states. This can be the much-needed reform at the branch level for credit expansion. Further, introduction of differential credit-starved regions or states should be considered. Small and marginal holding constitute approximately 95 per cent, 82 per cent and 86 per cent of total operational holding in the eastern and north-eastern regions respectively and for, these regions they said targets should be of higher order. It also seems desirable to have more concessional credit schemes for tribal, draught prone and hilly areas as these regions deserve a special attention for their speedy development

- There is also a dual problem of overlapping or dual financing among the financial institution as some people borrow multiple times from different institutions by cheating the rules and regulations or by utilizing their power at the same time. Thus, there should be check on the past data of the borrower and loans sanctioned in installments if and only if required.

- Financial institution should more clearly demonstrate the value in having bank account, as the under-banked often perceive non-bank financial services to be more convenient, faster, less expensive and presenting lower barriers to qualification. Banks should promote mobile technology to crease convinces, expedite the availability of deposited fund and make affordable the small credit loans available with streamlined but solid underwriting.

- In order to increase the deposit mobilization, banks should include the richer section of society in providing direct financial assistance and offer high interest rate in saving account and flexible credit policies as these sections have potential saving to deposit

\section{REFERENCES}

i John Friedman and William Alonso (ed), “Regional Development and Planning”. A 
International Journal of Social Science and Economic Research

ISSN: 2455-8834

Volume:05, Issue:09 "September 2020"

Reader, the M.I.T. Press, Cambridge 1967, pp- 3.

ii Praveen "Regional Disparities in India Economic Development" International Journal of Advance Research and Innovative Ideas in Education, Vol. 2, Issue 6, Ahmadabad, 2016, pp1203.

iii Ashok Kumar Tiwari, "Infrastructure and Economic Development in Himachal Pradesh", Indus Publishing Company, New Delhi, 2000, pp-22.

iv, G.P Kapoor, “Commercial Banking” A.P.H. Publishing Corporation, Ansari Road, New Delhi, 2004,

P-5.

v Bhawna Rajput, "Financial Inclusion and its Determinants: An Empirical Study on the InterState Variations in India" International Journal on Arts, Management and Humanities, Vol 6, No 1, New Delhi, 2017, pp 1-18.

vi Saluja," Banking Performance and Socio- Economic Development". Regal Publication, New Delhi, 2014, pp- 1-408.

vii T. Ravi Kumar, "Assessing Role of Banking sector in Financial Inclusion Process in India," Open Journal of Business and Management, Christ University, Bengluru, 2013, pp 1-28.

viii Chandan Kumar and Srijit Mishra, “ Banking Outreach and Household Level access:

Analyzing Financial Inclusion in India", $13^{\text {th }}$ Annual Conference on Money and Finance in the Indian Economy, Indira Gandhi Institute of Development Research, Mumbai, 2011, pp- 33-35.

ix Pankaj Kumar and Ramesh Golait, "Bank Penetration and SHGs Bank Linkage", Reserve Bank of India, Occasional Paper, Vol 29, No 3, New Delhi, 2009, pp 119-138. 